\title{
Analisis Keterampilan Proses Sains dan Self Regulation Biologi Kelas XI: Pengaruh Model Auditory, Intellectually dan Repatition (AUDI-IR)
}

\author{
Nukhbatul Bidayati Haka ${ }^{*}$, Vanny Dhea Pratiwi ${ }^{2}$, Bambang Sri Anggoro ${ }^{3}$, Abdul Hamid ${ }^{4}$ \\ 1)2)3) Universitas Islam Negeri Raden Intan Lampung \\ nukhbatulbidayatihaka@radenintan.ac.id, dheavannyp@gmail.com , bambangsrianggoro@ radenintan.ac.id, \\ abdulhamid@radenintan.ac.id
}

\begin{abstract}
ABSTRAK
Hasil pembelajaran biologi yang belum tercapai secara baik dikarenakan rendahnya kemampuan berpikir siswa. Pembelajaran secara umum belum melibatkan laboratory skills, terjadinya passive learning, kurangnya interaksi antar siswa, pembelajaran jarang melibatkan learning. Penelitian ini bertujuan untuk mengetahui pengaruh model pembelajaran Auditory, Intellectually, dan Repatition terhadap peningkatan Keterampilan Proses Sains dan Self Regulation pada peserta didik. Penelitian ini menggunakan metode quasi eksperimen dengan pretest dan posttest control group design, dengan teknik sampling Teknik acak kelas. Penelitian ini dilaksanakan di kelas XI di SMA Negeri 14 Bandar Lampung yang diterapkan dikelas kontrol (XI MIA2) dan eksperimen (XI MIA3) pada materi sistem pencernaan tahun ajaran 2019/2020. Instrumen penelitian menggunakan tes dan lembar observasi keterampilan proses sains, angket Self Regulation. Analisis data menggunakan uji MANOVA. Berdasarkan hasil penelitian diketahui nilai ngain KPS kelas kontrol 0.45 (sedang) dan kelas eksperimen 0.67 (sedang), sedangkan nilai ngain self regulation kelas kontrol 0.36 (sedang), dan kelas eksperimen 0.52 (sedang). Sehingga dapat disimpulkan bahwa sig. 0,000 $<0,05$ artinya terdapat pengaruh model pembelajaran Auditory, Intellectually, dan Repatition terhadap keterampilan proses sains dan self regulation pada kelas XI.
\end{abstract}

Kata kunci: Biologi, Model Pembelajaran Auditory, Intellectually, dan Repatition, Keterampilan Proses Sains, Self Regulation

\section{ABSTRACT}

Biology learning outcomes that have not been well achieved due to the low ability of students to think. Learning generally does not involve laboratory skills, the occurrence of passive learning, lack of interaction between students, learning rarely involves learning society. This study aims to determine the effect of learning models Auditory, Intellectually, and Repatition on improving Science Process Skills and Self Regulation on students. This study uses a quasi-experimental method with pretest and posttest control group design, with cluster random sampling techniques. This research was conducted in class XI at SMA Negeri 14 Bandar Lampung which was applied 
in the control class (XI MIA2) and experiment (XI MIA3) on digestive system material in the academic year 2019/2020. The research instrument used tests and observation sheets for science process skills, questionnaire Self Regulation. Data analysis using the MANOVA test. Based on the research results it is known that the KPS value of control class is 0.45 (moderate) and the experimental class is 0.67 (moderate), whereas the value of self-regulation is 0.36 (moderate), and the experimental class is 0.52 (moderate). So it can be concluded that sig. 0,000<0.05 means that there is an influence oflearning models Auditory, Intellectually, and Repatition on science process skills and self regulation in class XI.

\section{Keywords: Biology, Learning Model Auditory, Intellectually, and Repatition, Science Process Skills, Self Regulation}

\section{PENDAHULUAN}

Pendidikan merupakan sebuah usaha dalam menyiapkan diri seseorang dengan cara pengajaran, kegiatan bimbingan serta latihan supaya yang diharapkan bisa bermanfaat pada waktu yang akan datang. Tanpa melalui sebuah proses pendidikan, peserta didik tidak hanya dapat memahami apa yang dipelajari namun peserta didik pula bisa mendapatkan sebuah pengalaman dari apa yang dipelajari.(Gusnindar, Netriwati, \& Fredi, 2017:63). Maka pendidikan sangat dibutuhkan bagi peserta didik dalam mengembangkan potensi yang pada dasarnya mereka sudah memilikinya baik dari aspek afektif, kognitif bahkan psikomotorik. Dalam kualitas pendidikan bergantung kepada proses pembelajaran yang dilaksanakan di dalam kelas. Proses pembelajaran yakni sebuah kegiatan yang dilaksanakan oleh pendidik dengan baik agar perilaku peserta didik menjadi lebih baik.(Ernawati, Siska, Farida, \& Bambang, 2019:260). Untuk mempelajari sebuah ilmu sains pendidik bisa memberikan sebuah inovasi yang baru dalam melakukan kegiatan pembelajaran tersebut yang dimana peserta didik memiliki motivasi untuk melakukan kegiatan yang dapat menciptakan sebuah pengalaman bagi mereka selama mengikuti kegiatan pembelajaran seperti halnya peserta didik termotivasi untuk dapat memecahakan suatu masalah yang diberikan pada pendidik. Dengan melalui tahapan tersebut proses pembelajaran sains bisa dilakukan dengan kesadaran apa yang dilakukan, apa yang dikerjakan serta paham atau tidaknya peserta didik dalam memahami apa yang dipelajari.(Mulyasa, 2017:5)

Berdasarkan hasil wawancara dan observasi yang telah dilakukan pada bulan April 2019 di SMA Negeri 14 Bandar Lampung yang menunjukan bahwa kurangnya kemampuan peserta didik dalam memecahkan suatu masalah yang diberikan oleh pendidik, hal ini disebabkan selama proses pembelajaran peserta didik cenderung pasif dikarenakan peserta didik masih terfokus akan materi yang disampaikan kepada pendidik secara terus menerus sehingga peserta didik kurang 
memiliki motivasi dalam mengembangkan keterampilan untuk bisa memecahkan suatu masalah. Sehingga hasil belajar yang diperoleh peserta didik dapat dikatakan sangat kurang. Hal ini tidak sesuai dengan kurikulum 2013 yang dimana peserta didik dituntut untuk lebih aktif selama melakukan proses pembelajaran.

Model pembelajaran Auditory, Intellectually, dan Repatition yakni model pembelajaran yang mengutamakan alat indra peserta untuk dapat memecahkan suatu masalah serta peserta didik juga dilatih dalam daya ingat yang mereka miliki selama mengikuti kegiatan pembelajaran.(Atik, Ferina, \& Ari, 2019:69). Menurut emran suherman dalam buku(Sohimin, 2014:30) Auditory memiliki arti jika dalam melakukan pembelajaran peserta didik harus dapat menyimak, mendengarkan, berargumentasi, berbicara, presentasi, serta mengemukakan pendapat yang mereka miliki. Intellectually merupakan proses pembelajaran yang menggunakan kemampuan berfikir (mind-on) dengan berlatih dalam konsetrasi serta berlatih dengan melalui penyelidikan, menemukan, mengidentifikasi, mencipta, memecahkan masalah, mengonstruksi dan menerapkan.(Fitri, Suartama, \& Sentosa, 2000:2). Repatition yang berarti pengulanagan yang dimana proses pembelajaran tertuju pada pemahaman, pemantapan dan perluasan peserta didik melalui pemberian tugas atau quis.(Huda, 2017:292). Dengan melalui ketiga tahapan tersebut bisa membantu peserta didik dalam membangun konsep pengetahuan yang mereka miliki dengan sangat aktif. Untuk dapat membantu peserta didik dalam meningkatkan keterampilan untuk memecahkan suatu masalah yang diberikan, maka pendidik dapat menggunakan keterampilan proses sains sebagai tolak ukur guna untuk melihat keterampilan serta kemampuan yang dimiliki oleh peserta didik.

Keterampilan proses sains merupakan seperangkat keterampilan yang digunakan oleh para ilmuan untuk melakukan sebuah penelitian.(Qomariyah, N, Mahadewi, \& Beni, 2014:79). Keterampilan proses sains merupakan sebuah tindakan dalam melakukan proses pembelajran untuk mendapatkan konsep materi, prinsip, fakta maupun bukti. Pada dasarnya kegiatan pembelajaran sains, selain dapat menjadikan peserta didik terlatih menguasi konsep materi yang diberikan, peserta didik juga dilatih untuk dapat mengembangkan keterampilan guna untuk membantu memecahkan suatu masalah melali kegiatan praktikum (observasi).(Astutik, Susanti, Madlazim, \& Nur, 2017:159). Selama melakukan kegiatan pembelajaran tersebut peserta didik pula dilatih untuk bisa memanajemen diri mereka sendiri dalam mengikuti kegiatan pembelajaran seperti memahami pemikiran sendiri, membuat planning yang efektif sebelum mengikuti kegiatan 
pembelajaran, menyadari serta menggunakan sumber-sumber informasi yang akan digunakan untuk proses pembelajaran, serta peserta didik juga dilatih dalam memberikan umpan balik antar peserta didik lainnya hal ini bertujuan agar tercapainya tujuan proses pembelajaran yang diharapkan. Dalam hal ini pendidik bisa menggunakan Self Regulation sebagai tolak ukur dalam mengontrol perilaku setiap individu pada peserta didik.(Nurwijiyanti, Jazulu, \& Widyastuti, 2017:39)

Self Regulation merupakan sebuah kemampuan yang pada dasarnya sudah dimiliki oleh setiap manusi yang berkaitan dengan kemampuan berfikir serta kemampuan dalam memanipulasi terhadap lingkungan, maka akan terjadi perubahan pada lingkungan dan akan tercapainya tujuan yang sudah ditetapkan.(Mu'min, 2016:4). Dalam hal ini dilakukan penelitian dengan menggunakan model pembelajaran Auditory, Intellectually, dan Repatition untuk dapat meningkatakan keterampilan proses sains pada serta didik untuk dapat memecahkan suatu masalah melalui kegiatan praktikum serta melatih peserta didik dalam mengontrol perilaku mereka selama mengikuti kegiatan proses pembelajaran dengan menggunakan Self Regulation.

\section{METODE PENELITIAN}

Pelaksanaan penelitian di SMA Negeri 14 Bandar Lampung, dengan jumlah peserta didik 33 pada setiap kelas XI MIA. Penelitian ini dilakukan pada bulan oktober pada tahun ajaran 2019/2020. Penelitian ini menggunakan metode Quasi eksperimen, desain penelitian The Matching Only and Pretest-Postest Control Group Design.(Wallen and Freankel, 1932:80). Populasi pada penelitian ini yakni kelas XI MIA pada semester ganjil SMA Negeri 14 Bandar Lampung pada tahun ajaran 2019/2020. teknik sampel dilakukan secara "Cluster Random Sampling”. Hasil pengambilan sampel tersebut penelitian ini menggunakan kelas XI MIA 3 sebagai kelas eksperimen dengan menggunakan model pembelajaran Auditory, Intelectually, dan Repatition dan kelas XI MIA 2 sebagai kelas kontrol dengan menggunakan model pembelajaran Jigsaw.

Teknik yang digunakan dalam pengambilan data yang diberikan dengan melakukan observasi, angket, tes, dokumentasi dan catatan lapangan. Untuk angket Self Regulation dan tes Keterampilan proses sains diberikan pada awal (pre-test) dan akhir (post-test) pada proses pembelajaran. Selanjutnya catatan lapangan, observasi, dan dokumentasi didapatakan selama proses pembelajaran berlangsung dan berlangsungnya kegiatan praktikum. Kemudian terkait metode observasi digunakan untuk melihat hasil belajar peserta didik pada psikomotorik. 
Teknik Pada uji normalied Gain (N-Gain) guna untuk melihat perbandingan dari hasil perhitungan nilai pretest dan postest yang diperoleh dari instrumen yang digunakan berupa tes keterampilan proses sains dan angket Self Regulation, dengan menggunakan rumus N-Gain = $\frac{\text { SPosttest-Sprettest }}{\text { Smaxs-Spreetest }}$.

Method used should be accompanied by references, relevant modivication should be explainde. Procedure anda data analysis techique should be emphasized to literature review article (Meltzer, 2002:1260). Uji hipotesis dengan menggunakan uji varian Multivariate (MANOVA) digunakan untuk bisa melihat adakah pengaruh dan berapa besar perubahan yang dihasilkan dari nilai rata-rata pada kelas kontrol dan kelas eksperimen.

\section{HASIL PEMBAHASAN}

Berdasarkan penelitian yang telah dilakukan peneliti menggunakan model pembelajaran Auditory, Intellectually, dan Repatition yang memiliki 3 tahapan yakni Auditory, Intellectually, dan Repatition dapat dilihat di bawah ini :

Tabel 1. Tahapan Pembelajaran Model Auditory, Intellectually dan Repatition

\begin{tabular}{ll}
\hline Tahapan Model AIR & \multicolumn{1}{c}{ Keterangan } \\
\hline Auditory & $\begin{array}{l}\text { Pada tahapan ini menggambarkan } \\
\text { peserta didik dilatih untuk bisa } \\
\text { menggunakan alat indra yang mereka } \\
\text { miliki dengan baik dalam }\end{array}$ \\
melaksanakan kegiatan pembelajaran \\
dengan cara menyimak, \\
mendengarkan, berbicara, \\
berargumentasi selama mengikuti \\
kegiatan pembelajaran.
\end{tabular}




\begin{tabular}{ll}
\hline & mereka dalam menyampaikan ide-ide \\
untuk dapat berfikir dengan kritis & \\
selama melaksanakan kegiatan & pembelajaran. (Winda, Hilarius, \& \\
& Julung Hendrikus, 2018:14) \\
\hline Repatition & Tahapan yang terakhir \\
menggambarkan peserta didik \\
mengerjakan sebuah soal yang berupa \\
quis yang diberikan oleh pendidik \\
guna untuk melatih daya ingat mereka \\
terkait materi yang sudah diberikan \\
selama mengikuti kegiatan \\
pembelajaran serta peserta didik \\
dilatih untuk mengingat kembali atau \\
mengulas kembali yang sudah \\
dipelajari selama mengikuti kegiatan \\
proses pembelajaran. (Martini, \\
Tripalupi, \& Haris, 2017:67)
\end{tabular}

Berdasarkan tabel 1 diatas merupakan sebuah tahapan-tahapan dalam menggunakan model pembelajaran Auditory, Intellecrually, dan Repatition, pada model pembelajaran ini dapat meningkatakan keaktifan serta kemandirian pada peserta didik dalam melaksanakan kegiatan pembelajaran. Oleh karena itu pendidik menggunakan keterampilan proses sains untuk melihat perkembangan peserta didik dalam memecahkan suatu masalah secara ilmiah, hal ini pendidik menggunakan Lembar Kerja Peserta Didik yang berfungsi untuk melihat keaktifan peserta didik dalam memecahkan suatu masalah secara mandiri, kritis, teoritis, dan ilmiah (Serly, Bambang, Nukhbatul, \& Akbar, 2018:257). Dalam penelitian ini Lembar Kerja Peserta Didik digunakan sebanyak 3x pertemuan. Pada setiap pertemuan peserta didik diajarkan untuk dapat memecahkan suatu masalah secara teoritis dan ilmiah secara individu dengan hal ini peserta didik akan memiliki kemampuan berfikir secara kritis serta melatih kemampuan berfikir ilmiah yang 
sebelumnya sudah mereka miliki, dalam penelitian ini menggunkan materi Sistem Pencernaan Pada Manusia yang dimana pada topik pemecahan masalah yang akan diberikan yakni menentukan jenis-jenis kandungan pada makanan sehari-hari. Pada pertemuan pertama peserta didik memecahkan suatu masalah untuk menentukan kandungan glukosa pada beberapa sampel yang sudah di berikan. Kemudian pada pertemuan ke dua peserta didik mencari adanya kandungan protein pada beberapa sampel yang telah ditentukan. Dan pada pertemuan terakhir adalah peserta didik melakukan percobaan dengan mencari adanya kandungan Karbohidrat pada beberapa sampel dan sampel yang digunakan yang berhubungan dengan kehidupan sehari-hari. Selama melaksanakan kegiatan percobaan tersebut peserta didik mengalami perubahan atau perkembangan yang sangat signifikan setiap pertemuannya, hal ini dapat di dilihat pada gambar di bawah ini :

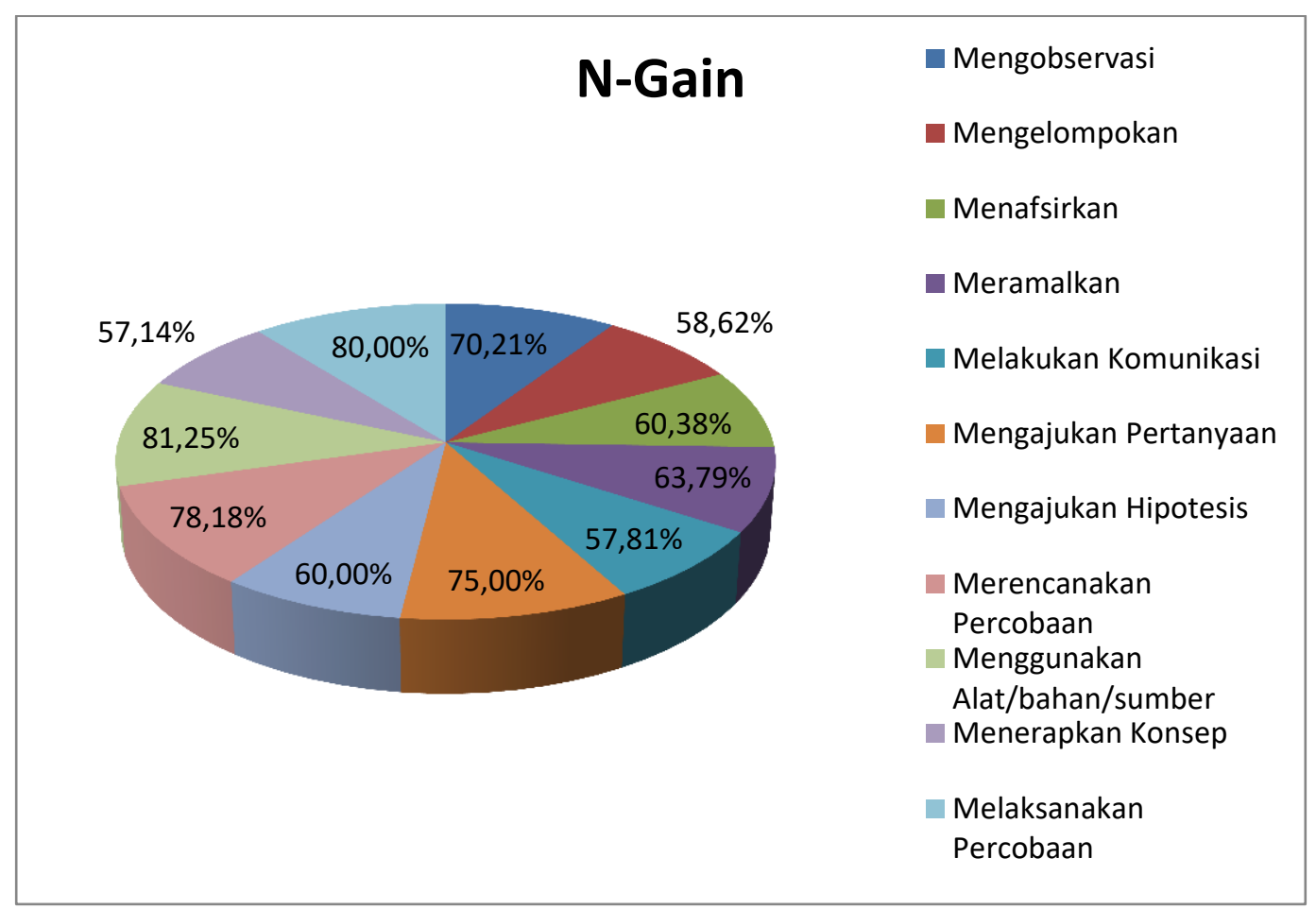

Gambar 1. Pencapaian Hasil Belajar KPS Kelas Eksperimen

Berdasarkan pada gambar 1 di atas merupakan hasil dari rekapitulasi perhitungan setiap pertemuan selama melakukan kegiatan percobaan dengan menggunakan Keterampilan Proses Sains pada kelas yang menggunakan model pembelajaran Auditory, Intellectually, dan Repatition atau disebut dengan kelas eksperimen. Berdasarkan perhitungan rekapitulasi maka memperoleh nilai rata-rata pada $\mathrm{N}$-gain yakni sebesar 0,67 . Kemudian adapun pencapaiann yang diperoleh 
pada kelas yang menggunakan model pembelajaran Jigsaw atau disebut dengan kelas kontrol yakni dapat dilihat pada gambar dibawah ini :

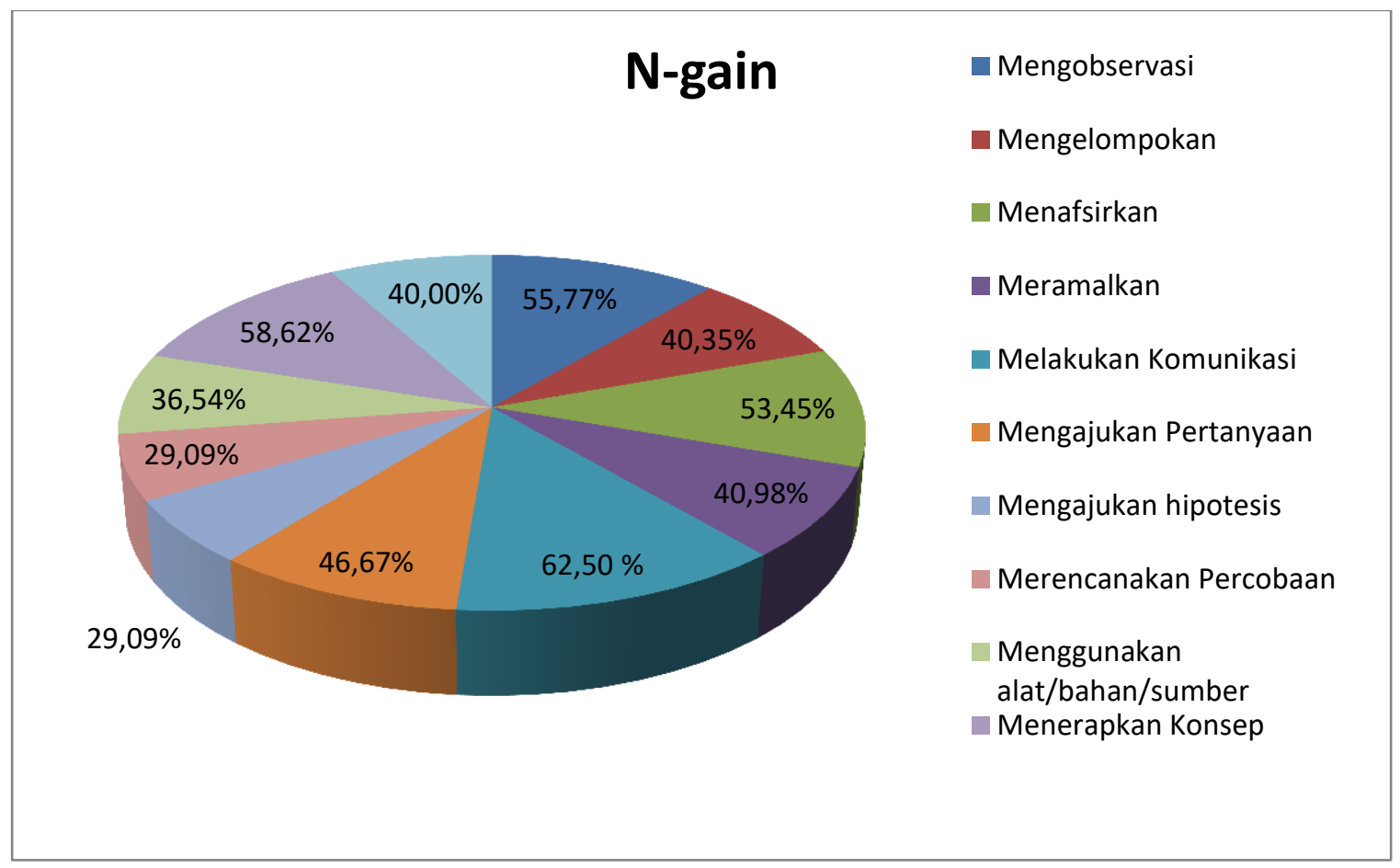

Gambar 2. Hasil Pencapaian Belajar KPS Kelas Kontrol

Berdasarkan pada gambar 2 di atas merupakan hasil dari rekapitulasi perhitungan setiap pertemuan selama melakukan kegiatan percobaan dengan menggunakan Keterampilan Proses Sains yang menjelaskan bahwa hasil perolehan nilai rata-rata pada N-gain yakni sebesar 0,45. Dalam hal ini menunjukan bahwa adanya perbandingan antara nilai rata-rata pada N-Gain pada kelas kontrol dan kelas eksprimen berbeda yang dimana pada kelas eksperimen memperoleh nilai rata-rata lebih tinggi dibandingkan dengan nilai rata-rata kelas kontrol. Dengan ini dapat dikatakan bahwa model pembelajaran Auditory,Intellectually, dan Repatition bisa meningkatan Keterampilan Proses Sains sebagai alat bantu pendidik dalam melaksankan kegiatan pembelajaran.

Berdasarkan keterangan diatas, dapat dikatakan bahwa persentase pada skor yang diperoleh dari N-Gain untuk setiap indikator keterampilan proses sains pada kelas eksperimen yang menerapakan model pembelajaran Auditory,Intellectually, dan Repatition memberikan perubahan serta perbandingan yang sangat baik jika dibandingkan dengan kelas kontrol yang menggunakan model pembelajaran Jigsaw. (Wawan \& Neri, 2018:69-70). Adapun hasil pencapaian yang diperoleh dari kelas eksperimen yakni dapat dilihat pada gambar dibawah ini : 


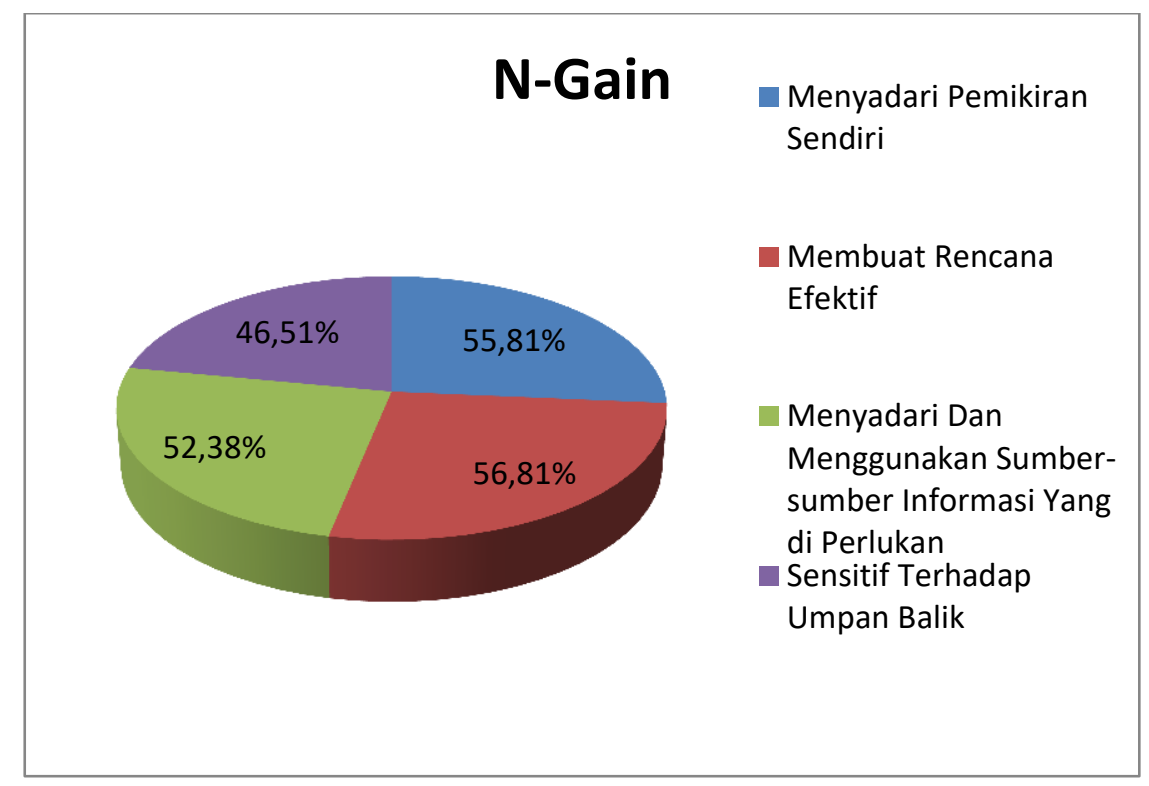

Gambar 3. Hasil Pencapaian Belajar Self Regulation Kelas Eksperimen

Berdasarkan gambar 3 diatas menjelaskan bahwa peserta didik mampu mengontrol perilaku mereka selama mengikuti kegiatan pembelajaran hal ini dapat dilihat melalui hasil pencapaian pada masing-masing indikator dengan memperoleh nilai rata-rata N-Gain yakni 0,52. Selanjutnya yakni hasil pencapaian hasil belajar pada kelas kontrol yakni dapat dilihat pada gambar di bawah ini :

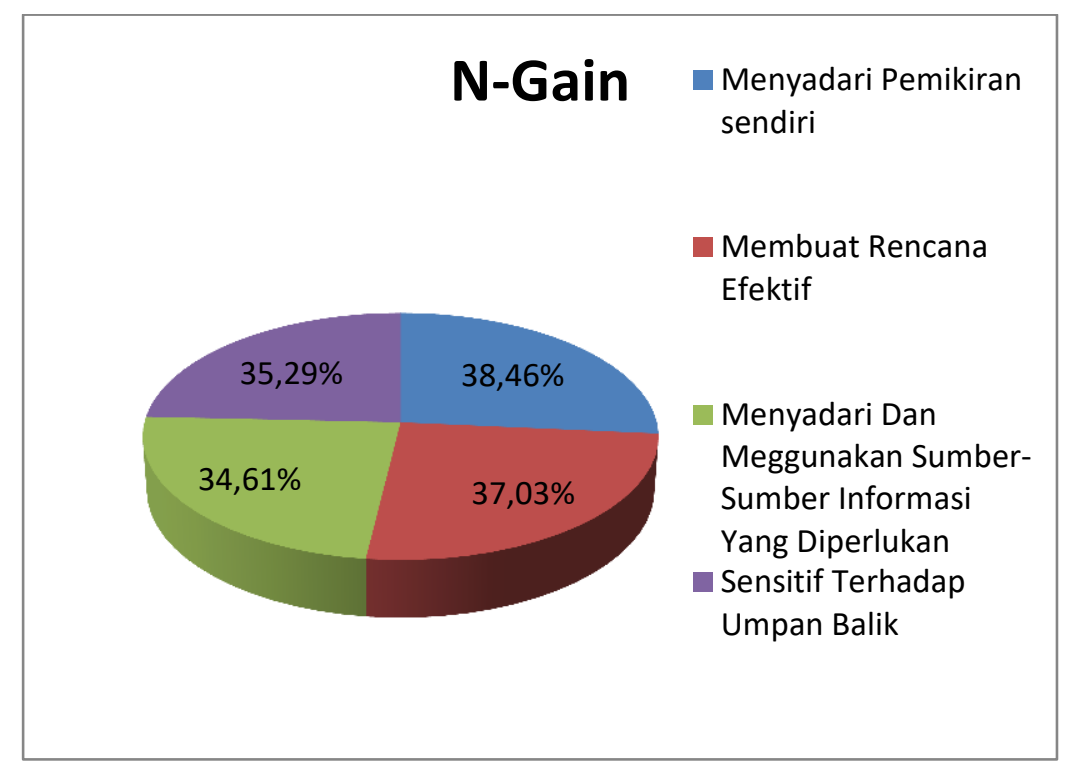

Gambar 4. Hasil Pencapaian Belajar Self Regulation Kelas Eksperimen 
Berdasarkan gambar 4 diatas menjelaskan bahwa peserta didik mampu mengontrol perilaku mereka selama mengikuti kegiatan pembelajaran hal ini dapat dilihat melalui hasil pencapaian pada masing-masing indikator dengan memperoleh nilai rata-rata N-Gain yakni 0,36.

Berdasarkan penjelasan diatas, dapat dikatakan bahwa persentase pada skor yang diperoleh dari N-Gain untuk setiap indikator Self Regulation pada kelas eksperimen yang menerapakan model pembelajaran Auditory, Intellectually, dan Repatition memberikan perubahan serta perbandingan yang sangat baik jika dibandingkan dengan kelas kontrol yang menggunakan model pembelajaran Jigsaw. Hal ini menunjukan bahwa pada dasarnya seorang pendidik hanyalah sebagai perantara ilmu dalam mentrasfer ilmu kepada peserta didik serta membimbing peserta didik dalam mencapai hasil belajar yang baik sesuai dengan tujuan pembelajaran, dengan ini peserta didik dituntut agar dapat meningkatkan kemampuan dalam berfikir secara kritis serta memperluas pemikiran mereka tidak hanya secara kognitif namun secara afektif dan psikomotorik agar mendapatkan sebuah pengalaman selama mengikuti kegiatan proses pembelajaran.(Serly et al., 2018). Berdasarkan hasil perhitungan pada keterampilan proses sains dan Self Regulation pada kelas eksperimen maupun kelas kontrol yakni terdapat hasil perbedaan dalam pencapaian hasil belajar hal ini dapat dilihat pada tabel dibawah ini :

Tabel 2. Perbedaan Pencapaian Hasil Belajar Kelas Eksperimen dan Kontrol

\begin{tabular}{cccc}
\hline \multicolumn{2}{c}{$\begin{array}{c}\text { Auditory, Intellectually, dan } \\
\text { Repatition }\end{array}$} & \multicolumn{2}{c}{ Jigsaw } \\
\hline $\begin{array}{c}\text { Keterampilan } \\
\text { Proses Sains }\end{array}$ & Self Regulation & $\begin{array}{c}\text { Keterampilan } \\
\text { Proses Sains }\end{array}$ & $\begin{array}{c}\text { Self } \\
\text { Regulation }\end{array}$ \\
\hline 0,67 & 0,52 & 0,45 & 0,36 \\
\hline & 0,59 & & 0,40 \\
\hline
\end{tabular}

Berdasarkan tabel 2 menunjukan adanya perbedaan terhadap pencapaian hasil belajar dalam menggunakan model pembelajaran Auditory, Intellectually, dan Repatition yang memperoleh rata-rata sebesar 0,59 sedangkan pada model pembelajaran Jigsaw memperoleh ratarata sebesar 0,40. Hal ini membuktikan bahwa model pembelajaran Auditory, Intellectually, dan Repatition merupakan salah satu alat bantu bagi pendidik dalam menjalankan proses pembelajaran sains dikarena dalam proses pembelajaran sains peserta didik diajarkan untuk mampu memahami sebuah konsep materi yang dipelajari serta mampu menghubungkan sebuah 
materi dengan fenomena yang nyata dalam hal ini menuntut peserta didik dapat lebih aktif dan kritis dalam memcahkan suatu masalah secara ilmiah, oleh karena itu pendidik memerlukan model pembelajaran yang yang sangat efektif dan inovatif dalam menarik perhatian peserta didik selama melaksanakan kegiatan pembelajaran sains terutama pada pembelajaran Biologi (Nining \& Nukhbatul, 2017:115). Dalam hal ini model Auditory, Intellectually, dan Repatition membuktikan bahwa model Auditory, Intellectually, dan Repatition merupakan salah satu solusi bagi pendidik untuk bisa membantu peserta didik agar bisa memberikan sebuah wawasan yang baru dengan mengembangkan ide-ide yang dimiliki peserta didik untuk dapat dikembangkan melalui kegiatan observasi /praktikum pada materi pembelajaran sains dengan bantuan keterampilan proses sains dalam hal ini peserta didik dilatih dalam menyelesaikan suatu masalah secara teoritis dan ilmiah baik secara kreatif dan inovatif. Kemudian model pembalajaran Auditory, Intellectually, dan Repatition dapat membantu peserta didik dalam mengontrol perilaku serta memanajemen tingkah laku mereka selama mengikuti kegiatan pembelajaran dengan bantuan Self Regulation hal ini dapat membantu jalannya proses pembelajaran yang kondusif.

Setelah melakukan perhitungan pada keterampilan proses sains dan Self Regulation selanjutnya dilakukan perhitungan uji hipotesis namun sebelum melakukan perhitungan pada uji hipotesis maka terlebih dahulu melakukan perhitungan pada uji prasyarat yakni uji homogenitas dan normalitas. Pada uji homogenitas menggunakan perhitungan Homogenitas Matriks-Varians dann uji Homogentias varians. Kemudian untuk uji normalitas menggunakan uji Kolomogorov Smirnov dengan bantuan SPSS 20.0.

Hasil perhitungan pada uji prasyarat normalitas pada keterampilan proses sains dan self regulation dengan menggunakan Kolomogorov smirnov yang dimana pada jenis didapatkan bahwa bahwa data berdistribusi normal. Selanjutnya yakni perhitungan pada uji homogenitas dengan menggunakan Homogenitas Matriks Varians-Konvarians yang memperoleh hasil pada Box's M = yakni 7.033 dengan taraf sig. Sebesar 0,079, maka berdasarkan hasil tersebut dapat diartikan bahwa $\mathrm{H}_{0}$ bisa dikatakan diterima. Dalam hal ini menunjukan bahwa pada variabel keterampilan proses sains dann Self Regulation memiliki tingkat kesetaraan pada kovarians matriks. Setelah melakukan perhitungan tersebut maka data bisa dilanjutkan dengan menggunakan perhitungan uji Homogenitas Varians yang dimana pada keterampilan proses sains pada kelas kontrol memperoleh taraf sig. 0,786 yang dimana >0,05. Sedangkan pada kelas eksperimen memperoleh taraf sig. 0,275 yang diamana >0,05, maka hipotesis dapat dikatakan 
nol yang berarti bahwa pada varians antar kedua kelompok pada model pembelajaran tidak ada yang berbeda sehingga $\mathrm{H}_{0}$ bisa diterima.

Setelah melakukan perhitungan pada uji prasyarat normalitas dan homogenitas yang menunjukan bahwa data yang diperoleh selama melakukukan penelitian bisa dikatakan berdistribusi normal dan homogen. Maka selanjutnya data tersebut dilakukan perhitungan uji hipotesis yang pertama dengan satu jalur dengan menggunakan uji Multivariate (MANOVA). Setelah dilakukan perhitungan dengan SPSS 20.0 dengan beberapa perhitungan statistik seperti Wilks' Lamda Hotelling's, Roy's Largesr Root dan Pilai's Trace maka diperoleh $F_{\text {hitung }}=62,527$ dengan taraf sig. 0,000 yang dimana $<0,05$ maka dapat diartikan bahwa adanya pengaruh model pembelajaran Auditory, Intellectually, dan Repatition terhadap peningkatakan keterampilan proses sains dan self regulation. Perhitungan dengan menggunakan uji Multivariate (MANOVA) bertujuan untuk melihat ada atau tidaknya perbedaan antara kedua variabel terikat yakni keterampilan proses sains dan self regulation. Pada perhitungan menggunakan uji uji Multivariate (MANOVA) terdapat pula beberapa uji statistik seperti Wilks' Lamda Hotelling's, Roy's Largesr Root dan Pilai 's.(Susi, 2016:40)

Selanjutnya perhitungan pada uji hipotesis yang kedua yakni menggunakan uji Test of between-subjects dengan menggunakan SPSS 20.0. berdsarakan perhitungan tersebut memperoleh nilai pada keterampilan proses sains dengan taraf sig. 0,000<0,05 dengan nilai $\mathrm{F}_{\text {hitung }}=29.919$, sehingga dapat dikatakan bahwa $\mathrm{H}_{0}$ ditolak dan $\mathrm{H}_{1}$ diterima maka dengan ratarata $Y_{1}$ sebagai variabel keterampilan proses sains memperlihatkan terdapat perbedaan dengan variabel X yakni model pembelajaran Auditory,Intellectually, dan Repatition.

Kemudian pada Self Regulation memperoleh taraf sig. 0,000 $<0,05$ dengan nilai $\mathrm{F}_{\text {hitung }}=$ 22.341, sehingga dapat dikatakan bahwa $\mathrm{H}_{0}$ ditolak dan $\mathrm{H}_{1}$ diterima maka dengan rata-rata $\mathrm{Y}_{2}$ sebagai variabel Self Regulation memperlihatkan terdapat perbedaan dengan variabel X yakni model pembelajaran Auditory, Intellectually, dan Repatition. Berdasarkan pemaparan pada perhitungan diatas maka dapat dilihat bahwa adanya perbedaan pada keterampilan proses sains dengan kelas eksperimen yang diberikan perlakukan menggunakan model pembelajaran Auditory,Intellectually,dan Repatition dan kelas kontrol yang diberikan perlakukan pada model pembelajaran Jigsaw. Oleh karena itu dapat dikatakan jila dalam pembelajaran dengan menggunakan model pembelajaran Auditory,Intellectually,dan Repatition bisa meningkatkan 
keaktifkan peserta didik serta melatih kemampuan peserta didik dalam berfikir dan mengotrol diri selama mengikuti kegiatan proses pembelajaran berlangsung.(Zeidan \& Jayosi, 2015:20)

Model pembelajaran Auditory, Intellectually, dan Repatition dapat digunakan dalam meningkatakan keterampilan proses sains dan Self Regulation, hal ini disebabkan model pembelajaran Auditory, Intellectually,dan Repatition bisa mengasah serta meningkatkan kemampuan peserta didik dalam daya ingat, kemudian peserta didik juga di latih dalam memecahkan suatu masalah dengan planning yang sudah terencana melalui kegiatan observasi, serta aktif dalam menyampaikan informasi melalui kegiatan komunikasi dengan mengajukan sebuah pertanyaan atau hipotesis.(Nisa Azisah, 2016:140-142).Dengan ini dapat disimpulkan bahwa adanya pengaruh model pembelajaran Auditory,Intellectually, dan Repatition terhadap peningkatan keterampilan proses sains dan self regulation pada peserta didik pada kelas XI di SMA Negeri 14 Bandar Lampung.

Hal ini sesuai dengan apa yang sudah dilakukan oleh Jaliami pada penelitiannyamengatakan jika model pembelajaran Auditory, Intellectually, dan Repatition dapat meningkatkan hasil belajar ilmu pengetahuan alam pada peserta didik melalui kegiatan ilmiah seperti praktikum dan bisa diterapkan dengan baik maka dapat meningkatkan keterampilan proses sains pada peserta didik.(R. \& Siti, 2013:88), sedangkan pada self regulation bisa membantu peserta didik dalam mengontrol diri serta memanajemen diri sendiri dalam mengikuti kegiatan proses pembelajaran. Jika self regulation diterapkan dalam setiap pembelajaran maka peserta didik memiliki motivasi belajar yang baik sehingga dapat mencapai hasil belajar yang maksimal sesuai dengan tujuan pembelajaran. (Bayuningsih, Udo, \& Subanti, 2017:52)

Dengan diterapkanya kegiatan diskusi, persentasi, serta praktikum pada peserta didik maka peserta didik dapat memahami pemikiran mereka dengan sendiri selama mengikuti proses pembelajaran, membuat planing yang tepat sebelum melaksanakan kegiatan proses pembelajaran, menyiapkan sumber-sumber informasi yang dibutuhkan sebagai penunjunag kegiatan proses pembelajaran sehingga dapat menambah wawasan baru bagi peserta didik dengan begittu peserta didik memiliki tingkat keaktifan yang baik dalam mengikuti kegiatan pembelajaran, serta mengasah daya ingat mereka dengan cara memahami konsep materi sesuai dengan pemahaman mereka sendiri. Dalam ini sesuai dengann kelebihan yang di miliki model pembalajaran Auditory, Intellectually, dan Repatition. 


\section{SIMPULAN}

Berdasarkan hasil dari penelitian yang telah dilakukan maka dapat di simpulkan bahwa kelas yang menggunakan model pembelajaran Auditory, Intellectually, dan Repatition menunjukan adanya perbedaan yang sangat signifikan hal ini dikarenakan model pembelajaran Auditory, Intellectually, dan Repatition dapat membantu kemampuan berfikir peserta didik secara teoritis, ilmiah dan juga kritis, hal ini dapat di lihat dari hasil rata-rata pada keterampilan proses sains dan self regulation yang digunakan sebagai tolak ukur penilaian terhadap kemampuan peserta didik baik dalam kognitif, afektif dan psikomotorik yang memperoleh nilai sebesar 0,59. Sedangkan pada kelas yang menggunakan model pembelajaran Jigsaw menunjukan perubahan yang dikategorikan cukup baik, hal ini di karenakan model pembelajaran Jigsaw dapat dikatakan kurang efektif untuk melatih kemampuan peserta didik dalam keterampilan proses sains dan self regulation hal ini dapat di lihat pada hasil perolehan rata-rata yakni 0,40 . Oleh karena itu model pembelajaran Auditory, Intellectually, dan Repatition dapat dikatakan efektif dalam melatih kemampuan berfikir peserta didik baik secara kognitif, afektif dan psikomotorik melalui keterampilan proses sains dan self regulation.

\section{DAFTAR PUSTAKA}

Astutik, N., Susanti, E., Madlazim, \& Nur, M. (2017). Effectiveness Of Collaborative Students Worksheet To Improve Students Affective Scientific Collaborational And Science Proses Skill (SPSS) Internasional. Jurnal Of Education And Reseach, 5(1). https://repository.unej.ac.id/handle/123456789/89492

Atik, B., Ferina, A., \& Ari, W. (2019). Pengaruh Motivasi Belajar Pada Penerapan Model AIR (Auditory, Intellectually, dan Repatition) Berbantu Media Kartu Soal Cerdas Terhadap Hasil Belajar Tematik Siswa Kelas V SDN Sampangan 02 Semarang. Jurnal Wahana Kreatifitas Pendidik, 2(2). https://ejurnalkotamadiun.org/index.php/WKP/article/view/289

Bayuningsih, A. S., UDO, B., \& Subanti, S. (2017). Analysis Of Junior High School Students Problem-Solving Ability Reviewed Self Regulated Learning, 2(1).

Ernawati, Siska, A., Farida, \& Bambang, S. A. (2019). Analisis Miskonsepsi Matematis: Dampak Pembelajaran Predict Discuss Explain Observe Discuss Explain. Desimal: Jurnal Matematika.ISSN:2613-9073 Online ISSN: http://repository.radenintan.ac.id/view/subjects/PB.html

Fitri, H., Suartama, I. K., \& Sentosa, I. P. P. (2000). Implementasi Model Pembelajaran Auditory, Intellectually,Repatition Untuk Meningkatan Aktivitas Dan Hasil Belajar Siswa. Jurnal Media Edukasi ISSN 2580-3844, 3(1). https://www.jurnal.undhirabali.ac.id/index.php/jmk/article/view/727 
Gusnindar, Netriwati, \& Fredi, G. P. (2017). Implementasi Strategi Pembelajaran Konflik Kognitif Berbantuan Software. JENS : Jurnal Edukasi Matematika Dan Sains. http://ejournal.unipma.ac.id/index.php/JEMS/article/view/1988

Huda, M. (2017). Model-Model Pengajaran Dan Pembelajaran. Yogya: Pustaka Belajar.

Martini, N. K., Tripalupi, L. E., \& Haris, I. A. (2017). Pengaruh Model Pembelajaran Auditory Intellectualy Repatition (AIR ) Terhadap Hasil Belajar Siswa Pada Mata Pelajaran Ekonomi Kelas X IPS Di SMA Negeri 3 Singaraja Tahun Pelajaran 2017 / 2018. ejournal Jurusan Ekonomi, 10(2). https://jurnal.unej.ac.id/index.php/e-JEBAUJ

Meltzer. (2002). The relationship between mathematics preparition and conseptual learning gains in physics: a possible, hidden variable. in diagnostic pretest scores. Am.J. Physic. Departemen of physics and Astronomy, lowa State Universiti, Ames, Lowa 5001. https://aapt.scitation.org/doi/abs/10.1119/1.1514215

Mu'min, S. . (2016). Regulasi Diri Dalam Belajar Mahasiswa Yang Bekerja. Jurnal AL-Ta'dib, 9(1). https://ejournal.unisba.ac.id/index.php/tadib

Mulyasa, E. (2017). Pengembangan Dan Implementasi Kurikulum 2013. Bandung: Remaja Roskarya.

Nining, K., \& Nukhbatul, B. H. (2017). Penggunaan Tes Diagnostik Two- Tier Multiple Choice Untuk Menganalisis Miskonsepsis Siswa Kelas X Pada Materi Archaebacteria Dan Eubacteria. Biosfer Jurnal Tadris Pendidikan Biologi.p-ISSN: 2086-5945 e-: 2580-4960, 8(1). http://repository.radenintan.ac.id/view/subjects/PB.html

Nisa Azisah. (2016). Pengaruh MetodeAutdoor Learning Terhadap Peningkatan Self Regulation Dan Keterampilan Proses Sains Siwa Kelas X Di SMA Gajah Mada Bandar Lampung. skripsi program S1 pendidikan biologi IAIN Raden Intan Lampung, Bandar lampung 2016. http://repository.radenintan.ac.id/view/subjects/PB.html

Nurwijiyanti, A., Jazulu, A., \& Widyastuti, E. (2017). The Description Of Students Matematical Problem-Solving Skiil And Self Regulation, 2(1).

Qomariyah, N, Mahadewi, M., \& Beni, S. (2014). Penerapan Model Pmebelajaran Guided Discovery Untuk Meningkatan Keterampilan Proses Sains Kelas VII. Jurnal Pendidikan Sainse-Pensa, 2(1). https://jurnalmahasiswa.un)esa.ac.id/index.php/pensa/article/view/7060

R., A. S., \& Siti, K. (2013). Efektivitas Model Pembelajaran Auditory Intellectually Repatition Dalam Pengajaran Matematika Di kelas VII MTS. PENDIDIKAN, Edu-ma-JURNAL.

Serly, G., Bambang, S. A., Nukhbatul, B. H., \& Akbar, H. (2018). Analisis Ketrampilan Proses Sains Dan Sikap Ilmiah Peserta Didik Kelas XI Mata Pelajaran Biologi Di SMA ALAZHAR 3 Bandar Lampung. Biosfer Jurnal Tadris Pendidikan Biologi.p-ISSN: 2086-5945 e-ISSN : 2580-4960, 9(2). http://repository.radenintan.ac.id/view/subjects/PB.html

Sohimin. (2014). 68 Model Pembelajaran Kurikulum 2013. Bandung: Bumi Aksara.

Susi, M. (2016). Metode Demonstrasi Interaktif Berbasis Inkuiri Dalam Pembelajaran Konsep 
Metabolisme Pada Siswa Kelas XII SMA Angkasa Bandung, 1(1). http://jurnal.biounwir.ac.id/index.php/mangiferaedu/article/download/59/38

Wallen and Freankel. (1932). How To Desaign And Evaluate Researh In Education Sixht Edition. In in E-Book.

Wawan, E. S., \& Neri, E. R. (2018). Penerapan Model Pembelajaran Children Learning In Science (CLIS) Dalam Pembelajaran Konsep Dasar IPA Untuk Meningkatan Ketrampilan Proses Sains Dan Sikap Ilmiah Mahasiswa Calon Guru IPA SD. Jurnal Pesona Dasa ISSN :2337-9227, $6(2)$. http://proceedings.conference.unpas.ac.id/index.php/sepeda/article/view/213

Winda, E., Hilarius, J. D., \& Julung Hendrikus. (2018). Penerapan Model Pembelajaran AIR (Auditory, Intellectually dan Repatition) terhadap Hasil Belajar Kognitif Siswa. jurnal Sainsmat, VII(1). https://jurnal.uns.ac.id/prosbi/article/view/5816

Zeidan, A. H., \& Jayosi, M. R. (2015). Science Process Skills And Attitudes To Coord Science Among Palestinian Secondary School Students. Jurnal Internasional, 5(1). 